\title{
KOMUNIKASI KESUKUBANGSAAN
}

\author{
Danang Susena ${ }^{1}$
}

Received Article: 13 Mei 2017

Accepted Article: 16 Juni 2017

\begin{abstract}
This article talking about basic of society use languange is unit for do social interaction between one of human to other human in one society contects with one's culture. Its more important different between society with one culture and society with different culture, such us sundaness which living at coastal areas, course very different with sundaness which living at hill areas, comparating with Jakarta society which is differences group ethnics society.
\end{abstract}

Key Words: Communication, Languange, Society, Ethnicity.

Pendahuluan

$\mathrm{D}$ alam masyarakat, setiap individu sebagai anggotanya akan melakukan interaksi sosial antar sesamanya, dan ini menggunakan bahasa yang diakui bersama. Tentu saja kemampuan berbaha sa sangat dipengaruhi oleh adanya gestur tubuh serta intonasi suara yang diucapkan yang pada dasarnya ditetapkan dan diakui oleh seluruh anggota masyarakatnya dengan kebudayaan yang sama.

Seperti halnya sebuah ujaran akan mempunyai makna ketika mengikuti atau diikuti oleh konteks sosial tertentu dan ini mendapatkan pengarahan dari aturan yang telah disetujui dan ditetapkan oleh seluruh anggota masyarakatnya, aturan ini sering dikatakan sebagai tata bahasa. Sehingga dengan demikian bahasa akan sesuai dengan konteks masyarakat tertentu dan situasi tertentu. Suara yang muncul dalam suatu konteks interaksi dalam masyarakat akan terkait dengan segala kaidah-kaidah tertentu yang biasanya diikuti oleh gerakangerakan tubuh yang berfungsi memperjelas makna dari ujaran yang diucapkan, atau dapat juga dikatakan sebagai tingkah laku linguistik.

\section{Pola-pola komunikasi}

T ingkah laku linguistik pada dasarnya diatur oleh sebuah aturan yang aturan tersebut bersumber dari kebudayaan.

Suara-suara yang diucapkan dalam sebuah bahasa pada dasarnya akan secara simultan berulang-ulang, suara-suara ini melekat pada kata-kata yang membentuk sederetan kalimat yang secara teratur dibentuk oleh aturan dan tata bahasa. Sehingga keluarnya kata-kata yang berbentuk bunyi akan mencirikan suatu pola yang berulang-ulang. Tata bahasa ini yang menjadi sumber dari aturan pembentukkan kalimat yang didasari oleh kebudayaan.

Ahli-ahli sosiolingusitik seperti Labov, Bailey dan Trudgill sudah menunjukkan bahwa apa yang dianggap oleh ahli linguistik sebelumnya sebagai ketidakbiasaan atau variasi bebas dalam tingkah laku linguistik dapat ditemukan suatu pola yang dapat diramalkan. Sedangkan para ahli etnografi komunikasi tertarik pada penemuan keajegkan dalam penggunaan bahasa, tetapi sementara itu ahli sosio linguistik memfokuskan pada variasi dalam pengucapan dan bentuk tatabahasanya. Para antropolog lebih tertarik pada

\footnotetext{
${ }^{1}$ Penulis adalah dosen Jurusan Sastra Indonesia Fakultas Sastra Universitas Andalas, Padang.
} 
bagaimana unit-unit komunikatif di organisir dan bagaimana mereka mempolakan dalam kelompok cara mengucap, seperti halnya dengan bagai mana pola-pola ini berhubungan secara sistematis dengan aspek lain dalam kebudayaan.

Pembentukan pola dalam bahasa akan terjadi pada seluruh tingkat komunikasi dalam masyarakat, kelompok

dan individu. Pada tingkat masyarakat, komunikasi biasanya mempolakan fungsi dari istilah-istilah, kategori dari ucapan, dan sifat serta konsepsi tentang bahasa dan ujaran. Komunikasi juga mempolakan cara bertutur mengikuti peranan-peranan khusus dan kelompok-kelompok dalam komunitas, seperti jenis kelamin, usia, status sosial dan pekerjaan: seperti guru mempunyai perbe daan cara bertutur dari pengacara, dokter, atau salesman asuransi. Cara bertutur juga mempolakan bahasa yang mengikuti tingkat pendidikan, penduduk kota atau desa, daerah geografi dan bentuk organisasi sosial.

Pada tingkat individu, komunikasi mempolakan tingkat ekspresi dan inter pretasi personal. Beberapa faktor emosi seperti gugup merupakan gejala pisiologi dan bukan bagian dari komunikasi, akan tetapi dalam kegugupan tersebut terdapat beberapa simbol-simbol yang termasuk dalam pola komunikasi. Contohnya seperti menaiknya temperamen suara merupakan gambaran dari sifat marah pada suatu komunitas tertentu, atau diam pada komunitas lainnya seperti orang-orang Indian di Amerika, atau mengangkat bahu bagi orang Papua yang dikategorikan mempunyai banyak arti dan sebagainya. Ketertarikan pada pola merupakan dasar dari antropologi dengan menginterpretasi yang didasari pada keterikatan arti pada penemuan dan deskripsi struktur atau disain normatif. Lebih jauh penekanan pada proses interaksi pada pola-pola tingkah laku yang diwujudkan.

\section{Fungsi komunikasi}

$\mathrm{P}$ ada tingkat komunitas, bahasa memberikan banyak fungsi. Dimulai dengan si pembuat aturan yang mempunyai peranan dalam menciptakan atau menekankan batasan dari kelompok Page | 28 nya, disamping itu juga menyatukan beberapa ujaran sebagai anggota dalam komunitas satu bahasa dan yang membedakannya dengan ujaran dari luar. Banyak hal dari bahasa juga dibuat untuk memberikan fungsi identifikasi sosial dalam komunitas dengan cara memakai indikator linguistik yang mungkin digunakan untuk menguatkan stratifikasi sosial. Penggamba ran linguistik sering digunakan komunitas secara sadar maupun tidak, untuk mengi dentifikasi dirinya dengan orang lain dan menjadikannya ciri serta memelihara kate gori sosial.

Pada tingkat individu dan kelompok yang berinteraksi satu dengan lainnya, fungsi komunikasi secara langsung dihubungkan dengan tujuan dan kebutuhan. Ini mencakup beberapa kategori fungsi sebagai penampakkan (perasaan atau emosi), tujuan/instruksi (kebutuhan atau pencarian), referen (benar atau salah), puisi (estetik), perasaan/phatic (bermusuhan atau solidaritas), dan metalinguistik (referen untuk bahasa sendiri). Atau seperti yang diketengahkan oleh Searle's (1977) yang memberikan kategori fungsi komunikasi untuk tingkat individu sebagai kelompok dari tindakan-tindakan illocutionary (kehadiran, arah/tujuan, penuh arti, membuat keje lasan), tetapi mempunyai perbedaan dalam pandangan dan batasan yang membagi lapangan etnografi komunikasi dengan teori ujaran atau pragmatik.

Bagi para antropolog, perspektif fungsional merupakan prioritas dalam deskripsi, satu kalimat tunggal mempunyai banyak fungsi secara simultan. Lebih jauh, sementara ahli teori ujaran dan ahli pragmatis secara umum berada di luar penampakkan/ metaphorical dan perasaan/ phatic menggunakan bahasa dari dasar kebersamaan. Komunikasi phatic mentrans misikan pesan, tetapi tidak mempunyai acuan arti. Arti ada dalam tindakan komunikasi itu sendiri. Banyak interaksi ritual dimasukkan dalam kategori ini.

Sebagian besar fungsi bahasa adalah universal, cara bekerjanya komunikasi pada setiap komunitas berdasarkan fungsi yang ada adalah bersifat khusus. Hubungan status yang sama dari dua ujaran mungkin terbawa oleh pilihan mereka dalam bentuk ujaran dalam satu bahasa; dan yang lainnya melalui jarak mereka berdiri dalam bagian atau posisi badan mereka sementara

Komunikasi Kebangsaan 
berbicara; serta antara bilingual, bahkan melalui pilihan mereka tentang bahasa yang digunakan untuk menunjukkan satu dengan lainnya.

Fungsi bahasa menyediakan dimensi utama untuk memberikan sifat dan meng organisir proses komunikatif dan mempro duksinya dalam sebuah komunitas; tanpa mengerti mengapa bahasa tersebut digu nakan untuk bentuk tersebut, dan konsekuensinya dari beberapa peng gunaan, hal itu tidak mungkin untuk mengerti arti-artinya dalam konteks interaksi sosial.

Mengklaim fungsi utama dalam bentuk analisa tidak mengesampingkan atau mengeluarkan struktur formal dari komunikasi; daripada menerima pengin tegrasian dari fungsi dan bentuk dalam analisa dan deskripsi. Kalimat dan bahkan hal-hal yang dipentingkan tidak sejalan dengan unit yang berdiri sendiri akan tetapi lebih sebagai disituasikan dalam setting komunikatif dan pola-pola dan sebagai fungsi mereka dalam komunitas.

\section{Komunitas Ujaran}

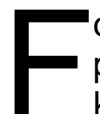
okus dari etnografi komunikasi adalah pada komunitas ujaran, dan pada cara komunikasi dipolakan dan diorganisir dalam unit tersebut Ahli-ahli linguistik secara umum setuju bahwa komunitas ujaran tidak dapat secara tepat sama dengan kelompok-kelompok komunitas yang berbicara bahasa yang sama. Seperti misalnya komunitas yang berbahasa Jawa di Padang dan komunitas Jawa di Yogyakarta tidak dapat dipersamakan arti dan fungsi bahasanya antara satu dengan lainnya walaupun menggunakan bahasa yang sama, ini terkait dengan kebudayaan mereka masing-masing yang bersifat khusus. Sehingga, walaupun menggunakan bahasa yang sama bentuk fungsi ujaran yang keluar akan berbeda satu dengan lainnya.

Seluruh definisi komunitas yang digunakan ilmu sosial memasukkan dimensi persebaran pengetahuan, kepemilikan, atau tingkah laku diambil dari bahasa latin communitae atau 'dikuasai umum' seperti kriteria sosiolinguistik untuk komunitas ujaran mencakup kata 'penyebaran/shared'.

Pertanyaan kunci dalam pendefi nisian untuk dipakai sebagai fokus studi adalah menyangkut persebaran dan penggunaan bentuk bahasa, batas geografi dan politik, kebudayaan dan sampai pada karakter pisik (warnakulit/ras). Pola-pola penggunaan bahasa, penginterpretasian, aturan berbicara, dan sifat yang terkait dalam bahasa merupakan bagian dalam penciptaan infestigasi etnografi.

Etnografi komunikasi harus dimulai dengan extra-linguistik yang mendefinisikan entitas sosial, bagaimana mereka mende finisikan dan mengorganisir serta menstrukturkan bahasanya, dan bagaimana mereka menghubungkan dengan organisasi sosial, serta bagaimana mereka memberi fungsi sebagai bentuk pola, dan meng integrasikan komponen dari komunitas secara keseluruhan.

Ada beberapa kriteria dalam men definisikan komunitas ujaran, antara lain:

1.

dalah kelompok dalam masyara kat yang mempunyai suatu kesamaan yang signifikan secara umum seperti: agama, suku bang sa, ras, usia, tuli, jenis kelamin, pekerjaan tetapi bukan warna dan tinggi.

2.

ia dibatasi oleh unit masyarakat secara fisik yang mempunyai kesempatan peran seperti: organi sasi politik, negara, usia yang sama, satu kelas, kelompok organisasi.

3.

umpulan dari kesamaan entitas situasi yang mempunyai sesuatu didalam umum, seperti: dunia barat, negara sedang berkembang, persa tuan bangsa-bangsa.

Ketergantungan pada derajad abstrak si, unit sosial diseleksi dalam tingkat yang berbeda, atau dibagi kedalam kelompokkelompok kecil yang merupakan bagian dalam kelompok yang lebih besar. Sehingga akhirnya dapat difokuskan ke dalam studistudi yang lebih terarah seperti, sebuah sekolah, pabrik atau komunitas gay, pendekatan etnografi terintegrasi akan melihat hubungan antar beberapa sub group sebagai satu kesatuan sosial budaya yang berisi peranan-peranan. Disini tidak diharapkan adanya kesamaan linguistik, tetapi yang diperlukan adalah adanya hubungan antar unit atau fokus tadi kedalam dimensi komunikasi sosial budaya 
seperti peranan dan domain. Bisa jadi antar unit tadi mempunyai bahasa yang berbeda. Yang jelas akan didapat suatu bahasa yang dipakai dalam peranan yang signifikan yang juga mengidentifikasikan batasan komunitas ujaran yang dipersepsikan oleh individu sebagai anggota komunitas tersebut.

Dalam tipologi informal dari komu nitas ujaran dikatakan sebagai 'kerang yang lembut' melawan 'kerang yang keras' yang dibedakan pada dasar kekuatan dari batas yang dipelihara oleh bahasa. Komunitas 'kerang yang keras' mempunyai batasan yang kuat, mempunyai interaksi yang minimal antar anggotanya dan anggota lain komunitas diluar komunitasnya dan menyediakan pemeliharaan bahasa dan kebudayaannya.

Bahasa sering juga dipakai untuk memberikan identitas tertentu suatu ke lompok dalam masyarakat yang lebih luas dimana si penutur dianggab sebagai ang gotanya. Seperti orang Jawa di Purwajaya (Payakumbuh, Sumatera Barat), dimana bahasa Jawa dapat dipakai di beberapa area seperti bahasa di rumah, dan interaksi sosial diantara anggota kelompok. Hal ini disebabkan karena orang Jawa juga dapat berbahasa Minangkabau dan mereka berpartisipasi penuh dalam komunitas ujaran yang lebih besar dan orang-orang juga berkesempatan belajar bahasa Jawa.

\section{Kemampuan Komunikatif}

$\mathrm{H}$ ymes mengobservasi bahwa penutur yang dapat memproduksi tatabahasa dalam kalimat bahasa tertentu akan dipranatakan jika mereka mencoba untuk melakukannya. Kemampuan komunikatif memasukkan tidak hanya kode-kode bahasa, tetapi juga apa yang dikatakan untuk siapa, dan bagaimana untuk mengatakan dalam setiap situasi yang ada.

Kemampuan komunikatif memperluas pada pengetahuan dan harapan pada siapa yang mungkin berkata dan siapa yang tidak, kapan mengeluarkan ucapan dan kapan tidak. Kemampuan komunikatif berisi tentang pengetahuan dan harapan dari orang-orang yang terlibat, bagaimana strategi mereka untuk memahami interkasi yang terjadi, apakah itu berkaitan dengan status, peranan, dan juga pemahaman yang akan terjadi di dalam komunikasi yang bersangkutan. Jelasnya, dalam setting Page | 30 sosial yang bersifat khusus, semua aspek kebudayaan yang menggunakan bahasa akan terjadi disitu.

Konsep dari kemampuan komunikatif pasti termaktup didalamnya kemampuan budaya atau keseluruhan pengetahuan dan kemampuan dimana penutur terlibat didalam suatu situasi. Pendekatan semiotik yang mendefinisikan kebudayaan sebagai pengertian dan pandangan dari para antropolog yang menyebut sebagai simbolsimbol. Sistem kebudayaan adalah polapola dari simbol-simbol dan bahasa hanya merupakan bagian dari sistem simbol dalam jaringan ini.

Berbagi pengetahuan budaya adalah dasar untuk menjelaskan tentang kebe naran dalam struktur bahasa, jadi akan menghubungkan bahasa yang diwujudkan dengan konteknya. Sementara referensi art mungkin diperoleh pada banyak elemen dalam kode-kode linguistik yang statis, pengertian dari situasi harus juga diperhitungkan sebagai suatu proses yang dinamis.

Kode-kode verbal mungkin ditransmisikan melalui oral, tulisan, atau saluaran manual. Muatan pada setiap saluran tergantung pada distribusi fungsi masing-masingnya dalam komunitas ujaran yang khusus, dan kesemuanya itu berbeda kepentingan dengan linguistik setiap individu dalam masyarakat. partisipasi penuh dapat dilakukan pada kelompok orang-orang tuli untuk mengerti kemampuan interaksi mereka dalam saluran manual dan bukan oral. Jadi deskripsi linguistik tradisional yang memfokuskan pada saluran oral akan juga mempunyai pandangan yang sempit untuk memperhitungkan kemam puan komunikatif dalam masyarakat secara umum.

Kebiasaan deskriptif memfokuskan pada produksi oral yang menaungi sifat bahasa sebagai gejala yang tidak langsung. Dalam anggapa alamiah dan lingkungan kemampuan komunikatif, hal ini sangat berguna untuk membedakan antara penerimaan dan menciptaan; hanya berbagi kemampuan menerima yang penting untuk suksesnya komunikasi.

Komponen-komponen komunikasi :

1.

Pengetahuan linguistik

a)

Elemen verbal

Komunikasi Kebangsaan 
b)

c) Elemen non verbal

Pola-pola dari elemen-elemen pa da kejadian-kejadian ujaran terten tu

d)

e)

Kemungkian dari varian-varian.

Arti dari varian-varian dalam situa si tertentu

1.

Kemampuan interaksi

a)

Persepsi gambaran umum yang

b) utama dalam situasi komunikatif

Seleksi dan interpretasi dari ke sesuaian bentuk pada situasi terten c) tu, peranan dan hubungan

d)

Pengorganisasian dan pemrosesan

e)

Norma-norma dari interaksi dan interpretasi

Strategi untuk pencapaian tujuan
2.
Pengetahuan budaya
a)
Struktur sosial
b)
Nilai dan atitut
c)
d)
Peta kognitif
Proses enkulturasi.

Kemampuan komunikatif mengacu pada pengetahuan dan kemampuan untuk penyesuaian terhadap konteksnya dalam bahasa di komunitas, kesemuanya itu mengacu juga pada pengetahuan komunikatif dan kemampuan berbagi dalam kelompok.

Kemampuan tentang ketidakmam puan Kemampuan komunikatif terdapat ketidak mampuan dalam bahasa ketika situasinya merupakan situasi yang diarahkan, misalnya orang dari strata lebih rendah berkomunikasi pada strata yang lebih tinggi, golongan minoritas terhadap golongan dominan, anak-anak terhadap orang dewasa.

\section{Daftar Pustaka}

Little John. 1996. System Theories" dalam Theories of Human Communication. Wadsworth Publishing Company : California.

Little John. 1996. "Theories of Symbolic Interaction, Dramatism, and Narrative " dalam Theories of Human Communication. Wadworth Publishing Company: California.

Saville-Troike, Muriel. 1990. "Basic Terms, Concepts, and Issues" dalam The Ethnography of Communication. An Introduction. Massachussetts: Basic Blackwell. 